\title{
Examining the children's perceptions of child rights
}

Berrin Akman, Hacettepe University, bakman@hacettepe.edu.tr, ORCID: 0000-0001-5668-4382

Dila Nur Yazıcı, Ondokuz Mayıs University, dilanur.yazici@omu.edu.tr, ORCID: 0000-0003-3340-4901

Abstract. This research was conducted to determine the perceptions of early childhood children's rights. A maximum diversity sample was used in the selection of the study group of the research that was formed in the phenomenology pattern of the qualitative research methods. In the survey where semi-structured interview questions were used, the content analysis was used in analyzing the answers. As a result of the research, it is suggested that children in early childhood should have rights such as playing games, having children go to school, having a home, having a meal, having a family, being friends, having children's rights in most cases and that the reasons for not using them are mostly related to home rules and routines. They were asked to play games, to go to the school, to eat, to be at home, in parallel with the first question. The findings of the research were discussed and suggested in the light of the related literature.

Keywords: Child, children rights, early childhood education

Received: 09.06.2018

Accepted: 25.08 .2020

Published: 15.01 .2021

\section{INTRODUCTION}

When the perspectives of philosophers from the past to the present are examined, it is seen that children do not have natural rights because they cannot use their cognitive skills completely. Therefore they should be under the protection and responsibility of their parents, and they follow the right path to the Universal Declaration of Children's Rights (Erbay, 2013a). Children's rights include "protecting children from harm and abuse; giving them a chance to grow up in emotionally appropriate style; rights that provide basic needs such as health, accommodation and education"(Neiken, 1998, p. 316). onsidering the rights of children, which are the future of each country, as an integral part of human rights, understanding of social freedom and the individual's emancipation will enable the child to adhere to these concepts in adulthood as well (Fazlığlu, 2007).

National and international studies for children started in the first half of the twentieth century and the scope of the studies carried out after this date has increased (Fazlıoglu, 2007). The first international decision on the protection of children was the Washington Decisions, and it was stated that those under the age of 14 should not be recruited, children under the age of 15 should be banned from working at night, and older children should not work more than eight hours a day, 48 hours a week (Tiryakioğlu, 1991). The first rigorous principles regarding the value and education of the child are the Geneva Declaration of Children's Rights dated September 26, 1924, also signed by Mustafa Kemal Atatürk. According to this declaration, the states parties decide that the child should be in favorable conditions in which the child can develop physically and spiritually naturally, that the hungry child should be fed, the sick child should be treated, the children with special needs should be developed as much as possible, the children should be helped first in times of disaster and should be protected against all kinds of exploitation. gave (Mufti, 2001). However, II. With the outbreak of the World War, this declaration could not be put into effect, so in 1948 the Geneva Second Declaration of the Rights of the Child was published. According to the principles in this declaration, the child; to have all human rights without any discrimination, to have social security, medical services and health care, to protect them from all aspects, to educate children with special needs, to have equal rights in terms of education and development, all kinds of neglect, abuse and exploitation It has been accepted by the state parties that there is a need for protection and love (Akarslan 1998).

After these international studies, the most significant step taken regarding children's rights is the Convention on the Rights of the Child, which was adopted by the United Nations 
General Assembly on 20 November 1989, and entered into force on 2 September 1990. With the Convention on the Rights of the Child, the rights of children have been accepted by the societies and the way for them to live as active individuals in the society has been opened by improving the citizenship status that comes with the birth of children (Doek, 2008). Approved by 200 countries worldwide, our country signed the contract on 09.12.1994 and entered into force on 27.01.1995. This contract; every individual under the age of 18 counts as a child, accepts the child as individuals with rights and responsibilities appropriate to his age and development level, emphasizes that the family has an important role in the life of the child, states that children have the right to express their views, and also the responsibilities of parents regarding their rights. It accepts that it is (Akyüz, 2010).

Child Rights Education, which came to the agenda for the first time in the "Children's Rights in Education Conference" held in Denmark in 1998; It ensures that children around the world come face to face with adults and other children every day in society, in their families, in individual relationships (Kent Kükürtçü, 2019; Washington, 2010). In the conference held in Denmark, suggestions such as developing appropriate materials and designing projects by including children's rights education in curricula were made (Kent Kükürtçü, 2019). The main objectives of children's rights education are: (a) To value oneself and others (b) To recognize and respect human rights in daily life (c) To understand our fundamental rights and to be able to translate them (c) To respect and value differences (d) Non-rigid (e) improving children's safety and abilities (Washington, 2010).

Studies conducted after the signing of the Convention on the Rights of the Child revealed that children are not aware of their rights and are not sufficiently informed about this issue. Upon this, countries started to include children's rights in their education programs (Howe \& Covell, cited in 2005: Ersoy, 2011). "It protects the rights of itself and others." In the article's explanation, "Awareness should be created with children through various activities based on the Convention on the Rights of the Child. Care should be taken to make a rights-based practice in all activities. Books on this subject should be read in accordance with the level of children, visuals should be examined, posters should be hung in the classroom. " (MEB, 2013, p.28). The introduction of child rights education to children from an early age is important for the development of a society that values the child, is sensitive to children's rights and supports the implementation of these rights (Covell \& Howe, 1999).

When the related literature is examined, a compilation about children's rights (Aral \& Gürsoy, 2001; Freeman, 1992; Woodhouse, 1993; Schoeman, 1980; Canbulut, 2014; Macnaughton, Hughes \& Smith, 2007; Melton, 1996); The views of teachers and teacher candidates (Alderson, 1999; Allan \& I'Anson, 2004; Covell \& Howe, 1999; Fazlıoğlu, 2007; Kor, 2013; Ochaita \& Espinosa, 1997; Osler \& Starkey, 1998; Neslitürk \& Ersoy, 2007; Waldron and Oberman, 2016); children's rights and media (Büyükbaykal, Mengü and Büyükbaykal, 2007; Cangöz, 2006; Moeller, 2002; Özmen, 2012; Salihoğlu, 2007); scale development studies (Karaman Kepenekçi, 2006; Yurtsever, 2009; Rogers and Wrightsman, 1978; Morton and Dubanoski, 1980; Melton, 1980; Ruck, 1994); parental views (Sutton, 2003; Morine, 2000; Wolfe, 1998; Dinç, 2015; Frankenberg, Holmqvist, \& Rubenson, 2014); the right to participate (Erbay, 2013b; Nayır \& Karaman Kepenekçi, 2011; Şahin \& Polat, 2012) the views of children in the concrete and abstract operations period (Emerson \& Lloyd, 2016; Ersoy, 2011, Melton, 1980; Ruck, Keating, Abramovitch and Koegl, 1998; Tereseviciene and Jonyniene, 2001; Gültekin, Gürdoğan Bayır and Balbağ, 2016); However, there is only one study (Uysal Bayrak, Gök, Yörük, \& Kaya, 2020) that examines children's views on children's rights in early childhood. Based on the importance of talking to children about their rights and providing them with an opinion, the aim of this study is to determine the perceptions of children in early childhood regarding children's rights. For this purpose, answers to the following questions were sought:

1. Is there a difference between the perceptions of the rights that boys and girls have?

2. Is there a difference between the perceptions of children's rights in the age group of five and six? 
3. Is there any difference in boys and girls' views about exercising the rights they think they have?

4. Is there any difference in children's opinions in the age group of five and six on using the rights they think they have?

5. Are there any differences in the definitions of boys and girls children's rights?

6. Is there any difference in the definitions of children's rights for children in the age group of five and six?

\section{METHOD}

In this study, phenomenology, one of the qualitative research methods, was used. The basic question in phenomenology is "What is the meaning, structure and essence of the person's group or person's experience of the phenomenon studied?" (Patton, 2002). In this design, a single concept or idea is expressed and a phenomenon to be investigated is emphasized (Creswell, 2013). The phenomenon in this study is the perceptions of children in early childhood regarding "children's rights".

\section{Study Group}

The study group of this research consists of 69 children who attend preschool education and show typical development. It is the first year of the age group 5 and the second year of the six age group. Maximum diversity sampling, one of the purposeful sampling methods, was used in the selection of the study group. The aim of maximum diversity sampling is to create a relatively small study group and to reflect the diversity of individuals who can be a party to the problem being studied in this study group (Ylldırım \& Şimşek, 2011). In this study, maximum diversity was created by equalizing girls and boys with 5 and 6 age groups, and the differences between these groups were examined in the analyzes. The demographic information of the study group is given in Table 1.

Table 1. Children's demographic information

\begin{tabular}{lc}
\hline Gender & $f$ \\
Girl & \\
Boy & 35 \\
Total & 34 \\
\hline Age & $\mathbf{6 9}$ \\
5 & \\
6 & 36 \\
Total & 33 \\
\hline
\end{tabular}

When Table 1 is examined, it is seen that 35 of the children participating in the study are girls, 34 are boys, 36 are in the age group of five and 33 are in the age group of six.

\section{Data collection tool}

A semi-structured interview form and a demographic information form were used in this study to determine children's perceptions of children's rights. The demographic information form contains information on the age, gender and grade of the children. The researchers created semistructured interview form after the related literature was reviewed and sent to two field experts. Field experts have approved the questions. Interview questions consist of three questions. Following the field experts' approval, a pilot interview was held with five children and the appropriateness of the questions was tested. After the pilot interviews, the first question was asked as the last question, the second question became the first question, and the third question became the second question. 


\section{Data Collection}

In order to collect the data, first the permission of the ethics commission was obtained and then the permission of the Ministry of National Education was obtained. The data were collected using face-to-face interview technique between 6-23 March 2017, after obtaining the necessary permissions from the parents. Interviewing, which is one of the most frequently used data collection methods in social sciences, has strengths such as flexibility, response rate, non-verbal behavior, control over the environment, question order, instant response, verification of the data source, completeness and in-depth information (Bailey, 1982). Interviews with the children took place in an empty room of the school where they were attending. There is a table and two chairs in the room, and no objects that could distract the children were found in the room. Before the interviews, necessary explanations were made to the children and it was stated that they might not answer the questions if they do not want to. All interviews were recorded with a tape recorder after obtaining permission from parents and children, and the interviews lasted between 4 and 7 minutes.

\section{Data Analysis}

In this research designed in line with qualitative research approach, "content analysis" method was used as data analysis. Content analysis is defined as the method used to express any qualitative data reduction and interpretation attempts to determine basic consistencies and meanings by taking large qualitative material (Patton, 2002). Content analysis; Creation of categories takes place in three stages: classification of categories and data, and naming the categories (Merriam, 2009). In order to ensure the internal validity of the study, the method of involvement of more than one researcher, one of the types of triangulation, direct quotations from children's sentences to ensure external validity, and the inter-coder consensus technique as a reliability method were used.

After all the research data were collected, the interviews were turned into written documents by a researcher in the computer environment. After this process was completed, 15 of the data (about $22 \%$ of the data) selected by the non-transcribing researcher through unbiased assignment were transcribed and verified. Subsequently, all data were reproduced in duplicate and one copy was named 5.1., 5.2., 6.1., 6.2... according to age groups, and one copy was named G.1., G.2, B.1, B.2 ... by gender. . In the next step, the researchers coded the data independently from each other and divided them into themes. Then the researchers came together and examined their codes and themes; They reached a consensus by talking about the issues with disagreement. After reaching a consensus, the codes and themes were arranged, and the findings were defined and interpreted.

\section{RESULTS}

\section{Findings Regarding the Rights They Have According to Children}

Table 2 shows that children's answers by gender to question"What rights do children have?" When Table 2 is examined, it is seen that the answers of girls and boys are categorized as play rights, accomodation / rest and nutrition, going to school, love and care and other. When the categories are examined; playing games in the game category (girl $=26$, boy $=22$ ), playing with plasticine (girl $=2$, boy $=1$ ) and going to the park (girl $=1$, boy $=4$ ); having a meal (girl $=4$, boy = 7) and having a home (female $=2$, boy $=4$ ) in the category of accommodation / rest and nutrition; In the school going category, going to school (girl $=7$, boy $=9$ ), painting (girl $=5$, boy $=2$ ), doing homework (girl $=2$, boy $=2$ ); having a family in the love and care category (girl $=2$, boy $=3$; having friends (girl $=2$, boy $=3$ ) and helping the mother in the other category (girl = 4; boy $=1$ ), watching cartoons (girl $=4$; male $=5$ ), having technological devices (girl $=4$, boy $=1$ ) and being respectful to adults (girl $=2$, boy $=1$ ) were given in common. 
Table 2. Children's awareness of children's rights by gender

\begin{tabular}{|c|c|c|c|}
\hline Girls & & Boys & \\
\hline Responses & $f$ & Responses & $f$ \\
\hline Play Rights & & Play Rights & \\
\hline Playing & 26 & Playing & 22 \\
\hline Having toys & 5 & Going to park & 4 \\
\hline Playing with silly putty & 2 & Having fun & 2 \\
\hline Going to park & 2 & Walking around & 2 \\
\hline Having bike & 1 & Playing with silly putty & 1 \\
\hline Learning chess & 1 & Playing with cars & 1 \\
\hline Making snowman & 1 & Playing with puzzle & 1 \\
\hline & & Running & 1 \\
\hline Total & 38 & Total & 34 \\
\hline Accommodation / Rest and Nutrition & & Accommodation / Rest a & \\
\hline Eating & 4 & Eating & 7 \\
\hline Sleeping & 2 & Having home & 4 \\
\hline Having home & 2 & Eating chocalate & 4 \\
\hline Wearing & 1 & Drinking someting & 3 \\
\hline Total & 9 & Total & 18 \\
\hline Going to School & & Going to School & \\
\hline Going to school & 7 & Going to school & 9 \\
\hline Picturing & 5 & Picturing & 2 \\
\hline Doing activities & 2 & Doing homework & 2 \\
\hline Doing homework & 2 & & \\
\hline Total & 16 & Total & 13 \\
\hline Love and care & & Love and care & \\
\hline Having family & 2 & Having friends & 4 \\
\hline Having friends & 2 & Having family & 3 \\
\hline Being child & 1 & Having brother/sister & 2 \\
\hline Getting what she wants & 1 & Not being sad & 1 \\
\hline Total & 6 & Total & 10 \\
\hline Others & & Others & \\
\hline Helping mother & 4 & Watching cartoons & 5 \\
\hline Watching cartoons & 4 & Helping mother & 1 \\
\hline Having technological tools & 4 & Being respectful to elders & 1 \\
\hline Being respectful to elders & 2 & Having technological tools & 1 \\
\hline $\begin{array}{l}\text { Doing the job she wants when she } \\
\text { grows up }\end{array}$ & 1 & I do not know & 1 \\
\hline Total & 15 & Total & 9 \\
\hline
\end{tabular}

G.1, G.18, G.31, B.1, B.6 and B.23stated the following.

"My grandfather takes me to the park, go to school, my family buy what I want, when I grow up, I don't do what I want." (G.1)

"They should go to the park, play games, have a home, sleep, go to school, watch cartoons." (G.18)

"He should have parents, he should help his mother. He should play games after helping his mother and then watch cartoons. " (G. 31)

"Traveling, having fun, watching cartoons. (B.1)

"Going to the park, playing, having siblings, going to school." (B.6)

"He has the right to play games with tablets, he has the right to go to school and paint, and he also has the right to eat chocolate." (B.23) 
Table 3 shows that children's answers by age to question"What rights do children have?"

Table 3. Children's awareness of children's rights by age

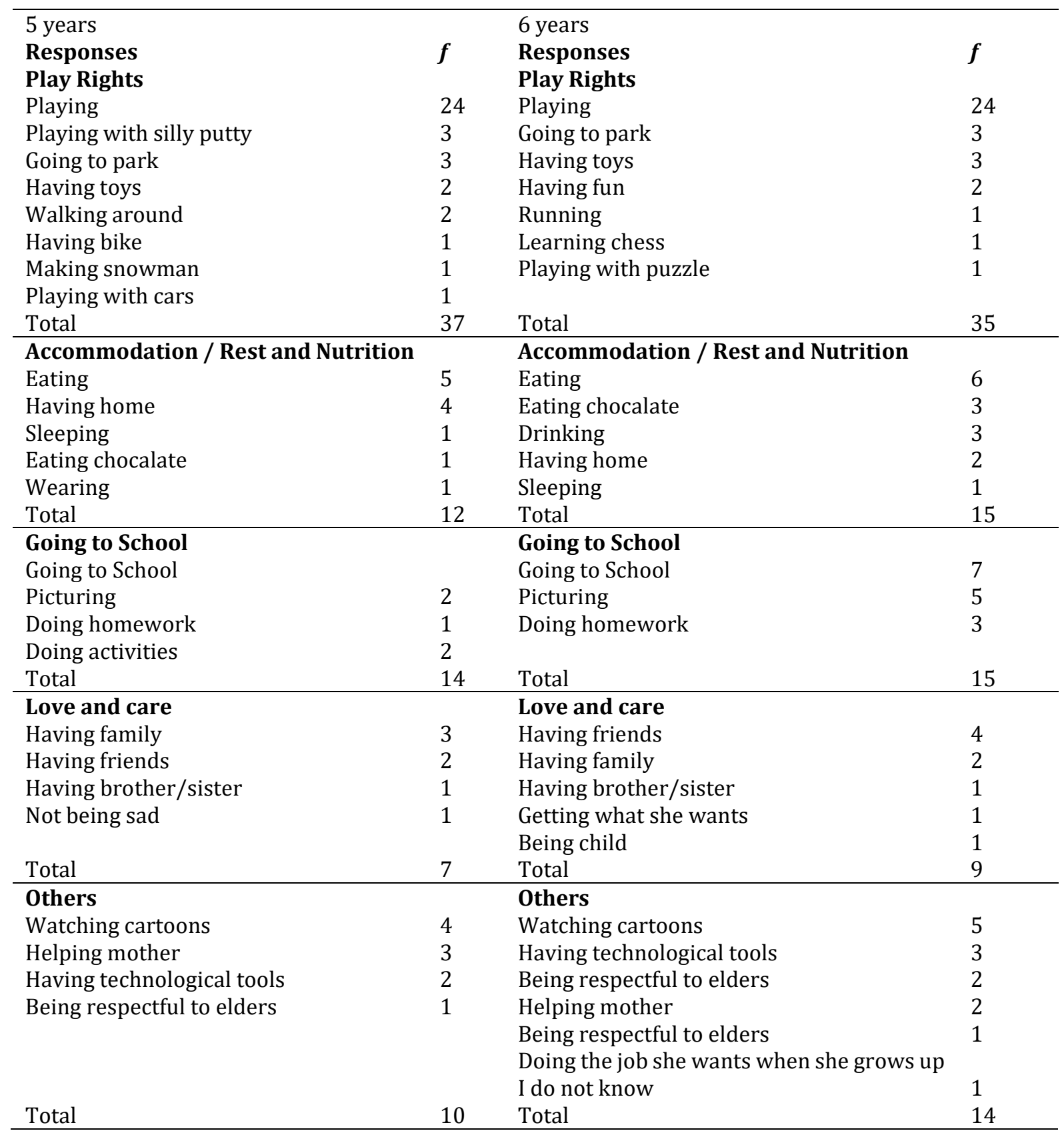

When Table 3 is examined, it is seen that the answers of the age group of five and six are categorized as play rights, accommodation / rest and nutrition, going to school, love and care and others. When the categories are examined; playing games in the game category ( 5 years $=24,6$ years $=24$ ), going to the park ( 5 years $=3,6$ years $=3$ ), having toys $(5$ years $=2,6$ years $=3$ ); Eating in the bar / recreation and nutrition category ( 5 years $=5,6$ years $=6$ ), having a home $(5$ years $=4,6$ years $=2$ ); going to school ( 5 years $=9,6$ years $=7$ ), painting ( 5 years $=2,6$ years $=$ 5 ), doing homework ( 5 years $=1,6$ years $=3$ ); family ( 5 years $=3,6$ years $=2$ ), friends ( 5 years $=$ 2,6 years $=4$ ), siblings ( 5 years $=1,6$ years $=1$ ), and cartoons in the other category. monitoring ( 5 years $=4,6$ years $=5$ ), helping the mother ( 5 years $=2,6$ years $=2)$, having technological devices ( 5 years $=2,6$ years $=3$ ) and being respectful to adults ( 5 years $=1,6$ years $=2$ ) answers 
were given as common. Regarding this issue, 5.5, 5.13, 5.22, 6.12, 6.20 and 6.30 stated the following.

"Making a snowman for snowfall." (5.5)

"Helping mothers, having a family, playing games and not being sad." (5.13)

"He has the right to have a house, to sleep there. And when her mother wants, she should help her. " (5.22)

"Must play games with I-Pad." (6.12)

"Going to school, having friends at school, painting and eating chocolate there." (6.20)

"My grandfather takes me to the park, go to school, my family buy what I want, when I grow up, I don't do what I want." (6.30)

\section{Findings Regarding the Exercise of Rights by Children According to Children}

Table 4 shows that children's answers by gender to question "Can you use these things that you think children have a right whenever you want?"

Table 4. Children's situations of their rights according to gender

\begin{tabular}{llll}
\hline Girls & & Boys & \\
Responses & $\boldsymbol{f}$ & Responses & 20 \\
Yes & 22 & Yes & 3 \\
Sometimes & 10 & Sometimes & 6 \\
No & 1 & No & 5 \\
No idea & 2 & No idea & \\
\hline
\end{tabular}

When Table 4 is examined, it is seen that 22 of the girls $(n=35)$ answered yes, 10 answered sometimes, one answered no, while 22 of the boys $(n=34)$ answered yes, three of them answered sometimes, and six answered no.

Table 5 shows that children's answers by age to question "Can you use these things that you think children have right whenever you want?"

Table 5.Children's situations their rights according to age

\begin{tabular}{llll}
\hline 5 years & & 6 years & $\boldsymbol{f}$ \\
Responses & $\boldsymbol{f}$ & Responses & 16 \\
Yes & 26 & Yes & 10 \\
Sometimes & 3 & Sometimes & 4 \\
No & 2 & No & 2 \\
No idea & 5 & No idea & \\
\hline
\end{tabular}

When Table 5 is examined, it is seen that 26 of the five age groups $(n=36)$ answer yes, three of them sometimes, and two of them answer no, while 17 of the six age group $(n=33)$ answer yes, 10 of them sometimes and four of them answer no.

Distribution of the children's answers whose answers are sometimes and no according to gender is given in Table 6. 
Table 6.Inability of children to exercise their rights according to gender

\begin{tabular}{|c|c|c|c|}
\hline Girls & & Boys & \\
\hline Responses (Sometimes) & $\boldsymbol{f}$ & Responses (Sometimes) & $f$ \\
\hline $\begin{array}{l}\text { Parents not always allowing computer / } \\
\text { tablet }\end{array}$ & 3 & Having hours for home activities & 1 \\
\hline Not always going to the park & 2 & $\begin{array}{l}\text { Not always able to play with the toys he } \\
\text { wants at school }\end{array}$ & 1 \\
\hline Inability to play after eating & 2 & Can't always eat chocolate & 1 \\
\hline $\begin{array}{l}\text { Inability to play while preparing to go to } \\
\text { school }\end{array}$ & 1 & & \\
\hline Take care of his brother & 1 & & \\
\hline $\begin{array}{l}\text { Inability to play as much as he wants at } \\
\text { school }\end{array}$ & 1 & & \\
\hline Parents angry & 1 & & \\
\hline Having hours for home events & 1 & & \\
\hline Total & 12 & Total & 3 \\
\hline Responses (No) & $f$ & Responses (No) & $f$ \\
\hline \multirow[t]{3}{*}{ I do not want to say } & 1 & Parents not giving permission & 2 \\
\hline & & Take care of his brother & 1 \\
\hline & & I do not want to say & 1 \\
\hline Total & 1 & Total & 4 \\
\hline
\end{tabular}

When Table 6 is examined, it is seen that girls sometimes have more answers and boys have more answers. When the answers given are examined, it is seen that the most common answers are that parents do not always allow a tablet / computer, cannot always go to the park, and cannot play after eating. Regarding this issue, G.8, G.11, B.11 and B.27 stated the following.

"My brother doesn't always allow." (G.8)

"I can't play the game I always wanted at school. Sometimes it happens to be the toy I want with a friend. " (G.11)

“When my parents sometimes ask me to play with my brother, I can't finish my game. (B.11)

"Sometimes. I can't do it in the evenings because my cartoon hour ends at eight. " (B.27)

The distribution of the answers of the children whose answers are sometimes and no by age is given in Table 7.

When Table 7 is examined, it is seen that the 6 age group sometimes has more answers, while the no answers are similar to each other in both age groups. Regarding this issue, 5.6, 5.30, 6.2 and 6.5 stated the following.

"If I play with the ball at home after 7 o'clock, the downstairs will be uncomfortable." (5.6)

"No, my mother won't let me go to the park." (5.30)

"I can use it sometimes. I can't play as much as I want at school. " (6.2)

"My father does not allow tablets all the time I want ..." (6.5) 
Table 7.Inability of children to exercise their rights according to age

\begin{tabular}{|c|c|c|c|}
\hline 5 Years & & 6 Years & \\
\hline Responses (Sometimes) & $f$ & Responses (Sometimes) & $f$ \\
\hline Inability to play after eating & 1 & $\begin{array}{l}\text { Parents not always allowing computer / } \\
\text { tablet }\end{array}$ & 3 \\
\hline Parents angry & 1 & Not always going to the park & 1 \\
\hline Not always going to the park & 1 & Inability to play after eating & 1 \\
\hline \multirow[t]{6}{*}{ Having hours for home activities } & 1 & $\begin{array}{l}\text { Inability to play while preparing to go to } \\
\text { school }\end{array}$ & 1 \\
\hline & & Take care of his brother & 1 \\
\hline & & $\begin{array}{l}\text { Inability to play as much as he wants in } \\
\text { school }\end{array}$ & 1 \\
\hline & & Having hours for home events & 1 \\
\hline & & $\begin{array}{l}\text { Not always able to play with the toys he } \\
\text { wants at school }\end{array}$ & 1 \\
\hline & & Can't always eat chocolate & 1 \\
\hline Total & 4 & Total & 11 \\
\hline Responses (No) & $f$ & Responses (No) & $f$ \\
\hline I do not want to say & 1 & Parents not giving permission & 1 \\
\hline \multirow[t]{2}{*}{ Parents not giving permission } & 1 & Take care of his brother & 1 \\
\hline & & I do not want to say & 1 \\
\hline Total & 2 & Total & 3 \\
\hline
\end{tabular}

\section{Findings Regarding the Definition of Children's Rights According to Children}

Table 8 shows that children's answers by gender to question "What are children's rights?"

Table 8.Definitions of children's rights by gender

\begin{tabular}{|c|c|c|c|}
\hline Girls & & Boys & \\
\hline Responses & $f$ & Responses & $f$ \\
\hline Play Rights & & Play Rights & \\
\hline Playing & 9 & Playing & 10 \\
\hline Having toys & 1 & Going to park & 2 \\
\hline \multirow[t]{2}{*}{ Going to park } & 1 & Having toys & 1 \\
\hline & & Driving toy car & 1 \\
\hline Total & 11 & Total & 14 \\
\hline Going to School & & Going to School & \\
\hline Children attending school & 5 & Children attending school & 2 \\
\hline Painting & 1 & Painting car & 1 \\
\hline Playing with silly putty & 1 & & \\
\hline Total & 7 & Total & 3 \\
\hline Accommodation / Rest and Nutrition & & Accommodation / Rest and Nutrition & \\
\hline Eating & 2 & Eating & 1 \\
\hline Having a home & 1 & Not sick & 1 \\
\hline Sleeping & 1 & Eating chocalate & 1 \\
\hline Growth & 1 & Eating snacks & 1 \\
\hline Being strong & 1 & & \\
\hline Total & 6 & Total & 4 \\
\hline Love and care & & Love and care & \\
\hline Do what you want & 2 & Friendship & 1 \\
\hline Giving children rights & 1 & Having brother/sister & 1 \\
\hline Being child & 1 & Do not upset the children & 1 \\
\hline Mothers not punishing & 1 & & \\
\hline Mother letting everything & 1 & & \\
\hline Not bored & 1 & & \\
\hline Total & 7 & Total & 3 \\
\hline
\end{tabular}


Table 8. Continued

\begin{tabular}{llll}
\hline Others & Others & \\
Do not hurt the mother & 3 & Loving animals & 2 \\
Helping mother & 2 & Do not hurt the mother & 1 \\
Being honest & 1 & Being respectful & 1 \\
Book title & 1 & Watching TV & 1 \\
Total & 7 & Total & 5 \\
I do not know & 7 & I do not know & 12 \\
\hline
\end{tabular}

When Table 8 is examined, it is seen that the answers of girls and boys are categorized as right to play, going to school, accommodation / rest and nutrition, love and interest and other. When the categories are examined; playing games in the game category (girl $=9$, boy $=10$ ), having a toy (girl = 1, boy =1), going to the park (girl = 1, boy = 2); children attending school in the school attendance category (girl $=5$; boy $=2$ ); It was observed that the answers were given to eat (girl = 2 , boy $=1$ ) in the housing / rest and nutrition category and not to upset the mother (girl = 3; boy $=1$ ) in the other category. It is seen that while girls and boys do not have common answers in the category of love and interest, seven of the girls and 12 of the boys give the answer I don't know. Regarding this issue, G.4, G.22, G.33, B.8, B.18 and B.32 stated the following.

"Having a house means sleeping when you get sleepy, my mother allowing everything when you wake up, not giving me any punishment." (G.4)

"Growing up and becoming stronger, eating and sleeping, going to school when you wake up." (G.22)

"It was the name of a book that our teacher read." (G.33)

"It means going to the park and playing games and having a brother. (B.8)

"It means that children never get sick, they always play games. (B.18)

"Eating, playing and loving animals." (B.32)

Table 9 shows that children's answers by age to question "What Are Children's Rights?"

Table 9. Definition of children's rights by age

\begin{tabular}{|c|c|c|c|}
\hline 5 years & & 6 years & \\
\hline Responses & $f$ & Responses & $f$ \\
\hline Play Rights & & Play Rights & \\
\hline Playing & 8 & Playing & 11 \\
\hline Going to park & 1 & Having toys & 2 \\
\hline Driving & 1 & Going to park & 2 \\
\hline Total & 10 & Total & 15 \\
\hline Going to School & & Going to School & \\
\hline Going to school & 6 & Going to school & 1 \\
\hline Painting & 1 & & \\
\hline Playing with silly putty & 1 & & \\
\hline Painting car & 1 & & \\
\hline Total & 9 & Total & 1 \\
\hline Accommodation / Rest and Nutrition & & Accommodation / Rest and Nutrition & \\
\hline Eating & 1 & Eating & 2 \\
\hline Having home & 1 & Not being ill & 1 \\
\hline Sleeping & 1 & & \\
\hline Being strong & 1 & & \\
\hline Eating chocolate & 1 & & \\
\hline Eating biscuits & 1 & & \\
\hline Growth & 1 & & \\
\hline Total & 7 & Total & 3 \\
\hline
\end{tabular}


Table 9. Continued

\begin{tabular}{|c|c|c|c|}
\hline Love and Care & & Love and Care & \\
\hline Having borther/sister & 1 & Do what they want & 2 \\
\hline \multirow[t]{6}{*}{ Mother letting everything } & 1 & Giving children rights & 1 \\
\hline & & Being child & 1 \\
\hline & & Mothers not punishing & 1 \\
\hline & & Friendship & 1 \\
\hline & & Not bored & 1 \\
\hline & & Do not upset the children & 1 \\
\hline Total & 2 & Total & 10 \\
\hline Others & & Others & \\
\hline Do not hurt the mother & 3 & Loving animals & 2 \\
\hline Being honest & 1 & Helping mother & 1 \\
\hline \multirow[t]{4}{*}{ Helping mother } & 1 & Do not hurt the mother & 1 \\
\hline & & Being respectful & 1 \\
\hline & & Watching TV & 1 \\
\hline & & Book title & 1 \\
\hline Total & 5 & Total & 7 \\
\hline I do not know & 10 & I do not know & 9 \\
\hline
\end{tabular}

When Table 9 is examined, it is seen that the answers of the age group of five and six are categorized as right to play, bar / rest and nutrition, going to school, love and interest and other. When the categories are examined; playing games in the game category ( 5 years $=8,6$ years $=$ 11), going to the park ( 5 years $=1,6$ years $=2$ ); children attending school in the school attendance category (age $5=5$, age $6=1$ ); It is seen that the responses of eating in the accommodation / rest and nutrition category ( 5 years $=1,6$ years $=2$ ) and not upsetting the mother in the other category ( 5 years $=3 ; 6$ years $=1$ ) are common. While there are no common answers in the love and interest category of the five and under age groups, it is seen that 10 of the five age group and 9 of the six age group give the answer I do not know. On this issue, 5.8, 5.10, 5.20, 6.18, 6.27 and 6.30 stated the following.

"Playing with play dough." (5.8)

"It is the right to be honest." (5.10)

"It is to play, to eat the biscuits he likes. (5.20)

"It means giving rights to children, of course!" (6.18)

"The mothers don't punish them when their kids misbehave. And having toys he wants. " (6.27)

"It means children never get sick, they always play games." (6.30)

\section{CONCLUSION AND DISCUSSION}

All children in the world legally or morally have the birth, education, health, shelter; Being defined as a universal concept used to define all rights such as protection against physical, psychological or sexual exploitation (Akyüz, 2010), giving children rights from an early age and raising children with the awareness of "rights" is an important individual and social situation (Covell and Howe, 1999; Ersoy, 2011). Based on this, this study examined the perceptions of children in early childhood regarding children's rights.

"What rights do children have?" When the answers given to the question are examined, it is seen that the answers of the children are categorized as the right to play, the right to shelter / rest and nutrition, the right to go to school, the right to love and attention and other rights. When the answers of the children participating in the study are examined, it is seen that the most 
frequently spoken answer depending on the age group is game. Newson et al. (1979) basically do not recognize play as activities of infinite flexibility that provide an opportunity for mind and spirit to harmonize with each other. Playing has an important place in the realization of learning in children, by offering natural learning environments to children, it provides their social, emotional, mental and physical development. (Jones, 2007). Similarly, in the study conducted by Uysal Bayrak et al. (2019), it was observed that children mostly answered this question on the right to play and education. In addition, Tereseviciene and Jonyniene (2016) found that although children's age group was older (12-14 years), the participants mentioned the right to play. In addition, in the same study, it was determined that the answers were given for children to have friends, to have clothes and food. Similarly, in the studies carried out by Covell and Howe (1999), Ersoy (2011) and Flight (2016), it was determined that children think they have the right to education, play and housing. These results are in line with the findings of the research. In this study, it is seen that one of the most common answers given by children is the category of accommodation / rest and nutrition. Considering Maslow's Hierarchy of Needs, this result appears to be an expected situation. According to Maslow (1943), people's basic needs such as eating, drinking and resting should be met first. Considering whether the answers of the children differ according to gender, it is seen that boys say more active activities than girls, such as traveling, having fun, running, and girls have the answers to having toys, learning chess, and snowmen. This situation may be due to the fact that boys like more active games and girls like games played with toys, such as house keeping. There are studies in the literature that support this finding. Lam and Leman (2003) state that children are choosing games and toys suitable for their gender from the age of four to five. Cook and Cook (2005) state that the rigidity in these preferences reached the highest level in the last years of the preschool period. When the answers in the other category are examined, it is noteworthy that there are answers to help the mother and to respect adults. It can be said that this situation stems from the Turkish family structure, traditions and customs. When the answers of the children are examined by age groups, it is seen that the groups generally give similar answers to each other.

"Can you exercise these rights whenever you want?" When their answers to the question are examined according to the gender of the children, 22 of the girls and 20 of the boys are yes; 10 of the girls, 3 of the boys sometimes; that 1 of the girls and 6 of the boys answered no; In terms of age, 26 of the 5 age group and 17 of the 6 age group are yes; 3 of 5 age group, 10 of 6 age group sometimes; It is seen that 2 of the 5 age group and 4 of the 6 age group have answered no. In the answers given sometimes and no, it is seen that the children are generally given answers about house rules and routines.

"What are children's rights?" When the answers given to the question are examined, it is seen that the answers given are categorized as the right to play, the right to shelter / food and rest, the right to go to school, the right to love and attention and others. In the study conducted by Ersoy (2011), the perceptions of primary school students (7-15 years) regarding children's rights were examined and similar to the study, it was determined that primary school children gave the answers to education, play and entertainment, housing and nutrition, attention and love, when it comes to children's rights. However, in the same study, it was seen that different answers were given such as life, expressing opinions and participating in decisions, political rights, not being employed, being free. In the study conducted by Flight (2016), it was seen that children between the ages of 9-14 formed metaphors of play, family, and education about children's rights. In the study conducted by Ruck et al. (1998), it was seen that the answers to play, education and being safe were common when it comes to children's rights, and it was determined that children in the older age group gave the answers such as human rights and legal rights.

In a study conducted by Gültekin, Gürdoğan Bayır, and Balbağ (2016) and Hareket and Yel (2017) with fourth grade students, children have rights to play, love and respect, shelter and nutrition, as well as the right to voice, the right to travel, the right to live, and the right to choose. 
It has also been determined that there are such answers. Similarly, in the study conducted by Covell and Howe (1999), it was found that children with an average age of 11.29 defined their basic needs and the right to education when it comes to children's rights; it was determined that freedom, respect and game answers were given. The difference in these answers was determined by Covell and Howe (1999), Ersoy (2011), Gültekin, Gürdoğan Bayır and Balbağ (2016) and Ruck et al. (1998) can be said to be due to the children in the study group and the children in this study being in different developmental stages. Children still rely heavily on perception and physical cues in the environment for learning and problem solving in the pre-operative period, which is the period in which the children in this study take part (Saçkes, 2013). When the answers given are examined, it is seen that the children give answers to the things that are happening or want to happen in their daily lives. For example, in a study conducted by Koçyiğit (2014), it was determined that preschool children see preschool education as a game. It is seen that children in other studies (Covell \& Howe, 1998; Ersoy, 2011; Gültekin, Gürdoğan Bayır, \& Balbağ, 2016; Ruck et al., 1998) are children involved in concrete and abstract operations. In the concrete operations period, children start to think logically and examine the parts to learn about the whole (Berk, 2012).

During the period of abstract operations that continue throughout adolescence, thoughts are quite flexible, and they find ways of thinking and logic in which they can justify their answers and solutions in the face of problems (Atay, 2012 Berk, 2012; Saçkes, 2013). When the answers given by the children were examined in terms of gender, it was seen that similar answers were given in the category of right to play, while it was found that in the shelter / rest and nutrition category, girls turned to more basic needs such as sleeping and growing, while boys turned to ready-made food. In the love and interest category, it was observed that boys gave answers for socializing such as having friends or having siblings, while girls gave more individual answers such as doing what they wanted, not being bored, and parents' allowing everything. When the answers given by the children are examined in terms of age groups, it is seen that they give similar answers in the right to play category, similar to gender, while it is seen that the five age group gave more detailed answers in the school going category. It can be said that the reason for this may be that the five-year-olds come to school with more meaning as they are their first year at school. Similarly, it is seen that five-year-olds give more detailed answers in the accommodation / rest and nutrition category, while six-year-olds give more detailed answers in the love and care category than the five-year-old group.

As a result, children in early childhood;

- They think they have the right to play, food / shelter and rest, go to school, love and attention,

- The majority of them think they can use these rights,

- When talking about children's rights, it was determined that they gave parallel answers to the first question such as play, schooling.

As a result of the research, the following suggestions can be made:

Suggestions for Researchers

- The research can be repeated as another study on comparing children who attend preschool education and those who do not.

- Parents and teachers can be trained on children's rights.

- More children's books could be published on children's rights.

- The research can be done by comparing the parents' socioeconomic and educational background.

Suggestions for Teachers

- Teachers can include more activities about children's rights in their plans. 


\section{REFERENCES}

Akyüz, E. (2010). Çocuk hukuku: Çocukların hakları ve korunması. Ankara: PEGEM.

Alderson, P. (1999). Human rights and democracy in schools do they mean more than "picking up litter and not killing whales. International Journal of Children's Rights, 7(3), 185-205.

Allan, J \&l'Anson, J. D. (2004). Children's rights in school: Power, assemblies and assemblages. International Journal of Children's Rights, 12(2), 123-138.

Bailey, K.D. (1982). Methods of social research. (2. Baskı). New York, NYC: The Free Press.

Bayır, Ö. G., Gültekin, M., \& Balbağ, N. L. (2016). Haklarımız var: Çocukların gözünden çocuk hakları. Adlyaman Üniversitesi Sosyal Bilimler Enstitüsü Dergisi, 24, 971-1005.

Büyükbaykal, C. I., Mengü, S. C.. \&Büyükbaykal, G. (2007). Üçüncü sayfadaki çocuk haberlerinin içerik analizi yöntemiyle değerlendirilmesi. 4. Uluslararası Çocuk ve İletişim Kongresi,( ss. 229-316). İstanbul: İstanbul Üniversitesi İletişim Fakültesi Yayınları.

Canbulut, T. (2014). Türkiye'de çocukların katılım hakkı üzerine bir derleme. Sağlık Bilimleri ve Meslekleri Dergisi, 1(2), 85-94.

Cangöz, İ. (2006). Gazete haberlerinde çocukların temsili. 2. Uluslararası Çocuk ve İletișim Kongresi: İletişimin Çocuğa Etkisi,(ss.587-596), İstanbul: İstanbul Üniversitesi İletişim Fakültesi Yayınları.

Covell, K. \& Howe, R. B. (1999). The impact of children's rights education: A Canadian study. The International Journal of Children's Rights, 7, 171-183.

Creswell, J. (2013). Qualitative inquiry\&research design- choosing among five approaches. California, CA: SAGE.

Dinç, B. (2015). Okulöncesi eğitim kurumuna devam eden çocukların ebeveynlerinin çocuk hakları eğitimi konusundaki görüşleri. Eğitimde Nitel Araştırmalar Dergisi, 3(1), 7-25.

Doek, J. E. (2008). Citizen child: A struggle for recognition. In A. Invernizzi ve J. Williams (eds). Children and citizenship içinde (ss.12-17). London: Sage.

Dunn, J. (2015). Insiders' perspectives: a children's rights approach to involving children in advising on adult-initiated research. International Journal of Early Years Education, 23(4), 394-408.

Emerson, L. \& Lloyd, K. (2017). Measuring children's experience of their right to participate in school and community: A rights-based approach. Children \& Society, 31(2), 120-133.

Erbay, E. (2013a). Çocuk hakları. İstanbul: Yeni İnsan.

Erbay, E. (2013b). Çocukların katılım hakkı üzerine bir Türkiye değerlendirmesi. İnsan ve Toplum Bilimleri Araștırması Dergisi, 2(1), 38-54.

Ersoy, A. F. (2011). İlköğretim öğrencilerinin çocuk haklarına ilişkin algıları. İlkoğretim Online, 10(1), 2139.

Faiz, M. \& Kamer, S. T. (2017). Prospective teachers' opinions concerning children's rights. Journal of Education and Learning, 6(3), 118-128.

Fazlığlu, Z. (2007). Çocuk hakları sözleşmesinde yer alan "Çocuk Hakları" konusunda öğretmenlerin ve yöneticilerin bilinç düzeyleri. Yayımlanmamış yüksek lisans tezi, Yeditepe Üniversitesi Sosyal Bilimler Enstitüsü, İstanbul.

Frankenberg, S. J., Holmqvist, R. \& Rubenson, B. (2014). In earlier days everyone could discipline children, now they have rights: Caregiving dilemmas of guidance and control in Urban Tanzania. Journal of Community \& Applied Social Psychology, 24(3), 191-204.

Freeman, M. D. (1992). Taking children's rights more seriously. International Journal of Law, Policy and the Family, 6(1), 52-71.

Gültekin, M., Gürdoğan Bayır, Ö. ve Balbağ, N.L. (2016). Haklarımız var: Çocukların gözünden çocuk hakları. Adlyaman Üniversitesi Sosyal Bilimler Enstitüsü Dergisi, 8(24), 972-1005.

Hareket, E., \& Yel, S. (2017). Which perceptions do we have related to our rights as child? Child rights from the perspective of primary school students. Journal of Education and Learning, 6(3), 340-349.

Heymann, J., Cassola, A., Raub, A. \& Mishra, L. (2013). Constitutional rights to health, public health and medical care: The status of health protections in 191 countries. Global Public Health, 8(6), 639653.

Jones, M. (2001). Oyun ve çocuk. Çev., Ayda Çayır. İstanbul: Kaknüs Yayıncılık.

Karaman-Kepenekci, Y. (2006). A study of university students' attitudes towards children's rights in Turkey. The International Journal of Children's Rights, 14(3), 307-318.

Kent Kükürtcü, S. (2019). Çocuk hakları ve demokrasi eğitiminin çocukların demokratik davranışlarına etkisi. Yayımlanmamış Doktora Tezi, Hacettepe Üniversitesi Eğitim Bilimleri Enstitüsü, Ankara.

Kor, K. (2013). Okul öncesi ögrretmenlerinin çocuk hakları konusundaki görüşlerinin belirlenmesi. Yayımlanmamış yüksek lisans tezi, On Sekiz Mart Üniversitesi Eğitim Bilimleri Enstitüsü, Çanakkale. 
MacNaughton, G., Hughes, P. \& Smith, K. (2007). Young children's rights and public policy: Practices and possibilities for citizenship in the early years. Children \& Society, 21(6), 458-469.

Maslow, A. H. (1943). A Theory of Human Motivation. Originally published in psychological review, 50, 370396. Classics in the History of Psychology. York University, Toronto.[Online].[Accessed 28th December 2006]. Available from World Wide Web:< http://psychclassics. yorku. ca/Maslow/motivation. htm.

MEB (2013). Okul öncesi eğitimi programı. http://ttkb.meb.gov.tr/program2.aspx?islem=1\&kno=202 adresinden 02.06.2017 tarihinde erişilmiştir.

Melton, G. B. (1980). Children's concepts of their rights. Journal of Clinical Child Psychology, 9(3) 186-190.

Melton, G. B. (1996). The child's right to a family environment: Why children's rights and family values are compatible. American Psychologist, 51(12), 1234-1238.

Moeller, S. D. (2002). A hierarchy of innocence-the medias use of children in the telling of international news. The Harvard International Journal of Press/Politics,7, 36-56.

Morine, S.J. (2000). Children's and parents' attitudes towards children's rights and perceptions of family relationship. Unpublished Master Thesis, Toronto University. Toronto, Canada.

Morton, T. L. \& Dubanoski, R. A. (1980). Children's rights: Attitudes and perceptions. Educational Researcher, 19, 24-27.

Nayır, F. \& Kepenekci, Y. K. (2011). Children's participation rights in elementary schools' Turkish textbooks. Elementary Education Online, 10(1), 160-168.

Neiken, D. (1998). Afterward: Choosing rights for children. G. Douglas ve L. Sebba (Eds), Children's rights and traditional values. Aldershot: Ashgate.

Neslitürk, S. \& Ersoy, A. F. (2007). Okulöncesi öğretmen adaylarının çocuk haklarının öğretimine ilişkin görüşleri. Eğitimde Kuram ve Uygulama, 3(2), 245-257.

Newson, E. J. \& Newson, E. (1979). Toys and playthings. Newyork, NYC.:Penguin books.

Ochaita, E. \& Espinoza, A. M. (1997). Children's participation in family and school life: A psychological and development approach. International Journal of Children's Rights, 5(3), 279-297.

Osler, A. \& Starkey, H. (1998). Children's rights and citizenship: Some implications for the management of schools. International Journal of Children's Rights, 6(3), 313-333.

Özmen, Ş. Y. (2012). Çocuğun adı yok: Televizyon haberlerinde çocuğun sunumu ve çocuk hakları bağlamında değerlendirilmesi. Gazi Üniversitesi İletişim Fakültesi Kuram ve Araştırma Dergisi, 34, 66-82.

Patton, M. Q. (2002). Qualitative research \& evaluation methods (3rd ed.). Thousand Oaks, CA: Sage.

Rogers, C.M. \& Wrightsman, L.S. (1978). Attitudes toward children's rights: Nurturance or selfdetermination? Journal of Social Issues, 34 (2), 59-68.

Ruck, M.D. (1994). Children's understanding of nurturance and self-determination rights. Unpublished Dissertation, Toronto University, Toronto, Canada

Ruck, M. D., Keating, D. P., Abramovitch, R. \& Koegl, C. J. (1998). Adolescents' and children's knowledge about rights: Some evidence for how young people view rights in their own lives. Journal of Adolescence, 21, 275- 289.

Sadık, F., \& Sarı, M. (2012). Çocuk ve demokrasi: ilköğretim öğrencilerinin demokrasi algılarının metaforlar aracılığıla incelenmesi. Cumhuriyet International Journal of Education, 1(1), 48-62.

Salihoğlu, S. (2007). 2006 yılında Türkiye'de üç yazılı basın organında yer alan çocuk haberlerinin analizi. Yayımlanmamış Yüksek Lisans Tezi, İstanbul Üniversitesi Adli Tıp Enstitüsü, İstanbul.

Schoeman, F. (1980). Rights of children, rights of parents, and the moral basis of the family. Ethics, 91(1), 6-19.

Sutton, P.B. (2003). The relationship between parents' attitude toward children's rights, parenting styles, and children's right to sexuality education. Unpublished Dissertation, Alliant International University, Fresno. California, USA.

Şahin, S. \& Polat, O. (2012). Türkiye'de ve dünyadaki gelişmiş ülkelerde çocuk katılım hakkı algısının ve uygulamalarının karşılaştırılması. Hukuk ve iktisat Araştırmaları Dergisi, 4(1), 275-282.

Tereseviciene, M. \& Jonyniene, Z. (2001). Students' perceptions of their rights in Lithuania. School Psychology International, 22, 152-173.

Uçuş, Ş. (2016). Exploring children's perceptions and metaphors on children's rights. Ahi Evran Üniversitesi Kırşehir Eğitim Fakültesi Dergisi, 17(3), 811-833.

Ulutaş, A. (2011). Okul öncesi dönemde drama ve oyunun önemi. Adıyaman Üniversitesi Sosyal Bilimler Enstitüsü Dergisi, 4(6), 232-42.

Uysal Bayrak, H., Gök, H. N., Yörük, E.\& Kaya, E. (2019). Okul öncesi dönemindeki çocukların gözünden çocuk hakları. Uluslararası Erken Çocukluk Eğitimi Çalışmaları Dergisi, 4(2), 63-73. 
Waldron, F., \& Oberman, R. (2016). Responsible citizens? How children are conceptualised as rights holders in Irish primary schools. The International Journal of Human Rights, 20(6), 744-760.

Woodhouse, B. B. (1993). Out of children's needs, children's rights: The child's voice in defining the family. Brigham Young University Journal of Public Law, 8, 321-341.

Wolfe, J.B. (1998). The relation between mother's and children's understanding of rights. Unpublished Dissertation, Toronto University, Toronto, Canada.

Yıldırım, A. \& Şimşek, H. (2011). Sosyal bilimlerde nitel araştırma yöntemleri. Ankara: Seçkin.

Yurtsever, M. (2009). Ebeveyn çocuk hakları tutum ölçeğinin geliş̧tirilmesi ve anne babaların çocuk haklarına yönelik tutumlarının farklı değişsenler açısından incelenmesi. Yayımlanmamış Doktora Tezi, Marmara Üniversitesi Ĕgitim Bilimleri Enstitüsü, İstanbul. 